\title{
Towards a Mental Representation of Vowel Height in SSBE Speakers
}

\author{
KEVIN MENDOUSSE* \\ University of Auckland
}

Received: 23 February 2011 / Accepted: 16 June 2011

\begin{abstract}
Vigorous debate in phonetics and phonology has focused on the structure and cognitive foundation of distinctive feature theory, as well as on the definition and representation of features themselves. In particular, we show in Section 1 that, although vowel height has long been the object of close scrutiny, research on the three- or moretiered height representation of vowels in the phonology of English remains inconclusive. Section 2 reports on the rationale and methodology of a sound-symbolism experiment designed to evaluate the implicit phonological knowledge that English native speakers have of vowel height differences. In Section 3 we tabulate results and argue in Section 4 that their intuitive understanding of such differences is best accounted for in terms of a threetiered height axis ${ }^{1}$.
\end{abstract}

KEYWORDS: binarism, distinctive feature, phonetic symbolism, phonological perception, vowel height.

\section{RESUMEN}

El intenso debate en la fonética y la fonología se ha enfocado en la estructura y en la base cognitiva de la teoría de los rasgos distintivos, así como en la definición y en la representación de los rasgos mismos. En concreto, demostramos en la Sección 1 que, aunque la apertura de las vocales ha sido durante mucho tiempo objeto de riguroso análisis, la investigación en torno a la representación de las vocales mediante tres o más grados de apertura no es concluyente en la fonología del inglés. La sección 2 informa sobre el razonamiento y la metodología de un experimento de simbolismo fonético diseñado para evaluar el conocimiento fonológico implícito con que cuentan los angloparlantes de Inglaterra respecto a los distintos grados de apertura vocálica. En la Sección 3 se tabulan los resultados, y sostenemos en la Sección 4 que la comprensión intuitiva de tales diferencias se explica mejor en términos de un eje con tres grados de apertura.

PALABRAS CLAVE: binarismo, rasgo distintivo, simbolismo fonético, percepción fonológica, apertura vocálica.

*Address for correspondence: Dr Kevin Mendousse, School of European Languages and Literatures, University of Auckland, Private Bag 92019, Auckland, New Zealand. Tel.: +64 9373 7599; Fax: +64 9373 7483; Email: k.mendousse@auckland.ac.nz 


\section{THEORETICAL FRAMEWORK}

\subsection{Binary feature theory}

Beneath the radical differences in the claims made in Preliminaries to Speech Analysis: the Distinctive Features and their Correlates (henceforth PSA, Jakobson, Fant \& Halle, 1952) and The Sound Pattern of English (henceforth SPE, Chomsky \& Halle, 1968) lies a shared belief that distinctive features must be binary if one is to formulate a universal and unified phonological theory of language. In the case of English, both these seminal works account for its vowel system by way of four paradigmatic feature oppositions: acoustic features [ \pm compact/diffuse], [ \pm grave/acute], $[ \pm$ flat/natural] and $[ \pm$ stressed/unstressed] in PSA terms, and articulatory features $[ \pm$ high/low], $[ \pm$ front/back], $[ \pm$ round/nonround $]$ and $[ \pm$ tense/lax $]$ in SPE terms.

Jakobson, Fant and Halle (1952) make no structural difference between the long monophthongs and diphthongs of Received Pronunciation English (henceforth RP English): both types of vowels are assigned a geminate nuclear structure composed of an initial stressed vowel followed by a non-syllabic vocalic off-glide, which is unstressed by definition and phonetically realized as either a centrifugal or a centripetal off-glide. In line with Trager and Smith's (1951) “simplex" vs “complex" structural analysis of English vowels, long monophthongs and diphthongs would thus be binuclear and in phonological opposition to the mononuclear structure of short monophthongs.

Yet, following Jones (1918), it had been the convention to isolate three types of vowel primes in varieties of English such as RP on the following grounds: a) as far back as Hart (1569), observers of English dialects have been able to distinguish three basic forms of phonetic vowel nuclei (i.e. short, long and diphthongal); b) there are hypothetically as many phonemic types as phonetically discernible. By adding the prosodic feature opposition [ \pm stressed/unstressed] to the phonological inventory of RP English vowels, Jakobson, Fant and Halle (1952) saw, as argued in Mendousse (2007), an opportunity to cut back on one type of vowel prime. This cost-effective taxonomy was in keeping with what was then Jakobson's (1949) dogmatic faith in the principle of Ockham's razor, and had the added advantage of downsizing Jones's inventory of twenty vowel phonemes in RP English to a mere twelve ${ }^{2}$.

Central to the PSA description is the assumption that the phonological feature in phonetic oppositions of the kind $[I] \sim[i:$ is not one of acoustic height, but one of simplex vs complex nuclear structure (i.e. /'i/ /'i i ㄱ/). Chomsky and Halle (1968), however, declared PSA too radical a model to account adequately for palatalisation, velarisation and pharyngealisation processes, or for the underlying symmetry between palatalisation and front vowels as well as between velarisation and back vowels. To this end, while supporting the need for a universal repertoire of binary distinctive features, Chomsky and Halle (1968) questioned Jakobson's law of economy and provided a rationale for an articulatory-based 
variant system where, phonologically, [ \pm high/low], [ \pm front/back] and [ \pm round/nonround] feature oppositions partly correspond to PSA [ \pm diffuse/compact], [ \pm grave/acute] and $[ \pm \text { flat/natural }]^{3}$.

With reference to the phonological description of English vowels, Chomsky and Halle (1968) also argued for the addition of the intrinsic feature opposition [ \pm tense/lax], by virtue of which underlying tense segments are made to undergo contextual derivations via two linearlyordered rules applying cyclically (Figures 1 and 2), both considered to be the synchronic residues of the diachronic shift that occurred in the pronunciation of Early Modern English long monophthongs:

$\phi \rightarrow\left[\begin{array}{c}- \text { voc } \\ - \text { cons } \\ + \text { high } \\ \alpha \text { back } \\ \alpha \text { round }\end{array}\right] /\left[\begin{array}{l}+ \text { tense } \\ \alpha \text { back }\end{array}\right]-$

Figure 1: Diphthongization Rule (Chomsky \& Halle, 1968: 183)

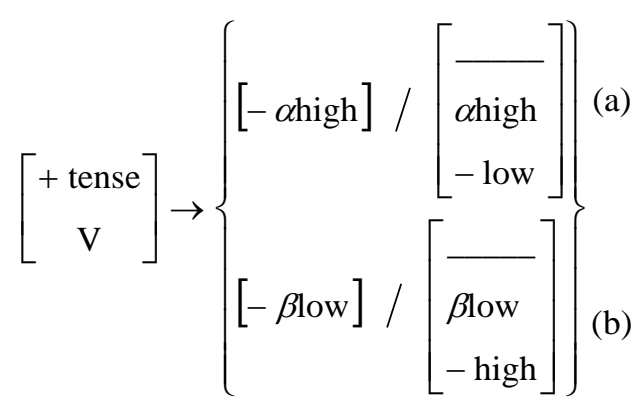

Figure 2: Vowel Shift Rule (Chomsky \& Halle, 1968: 187)

Surface vowels [I] and [i: ] would thus respectively derive from underlying lax /i/ and tense $/ \bar{\varepsilon} /$ in RP English, whereas they were previously assigned equal phonological height in PSA via the phonemic opposition /'i/ /'ii /. Conversely, where PSA admits a phonological height feature difference between $[\varepsilon]$ and $[i:$ ] via / ' $\varepsilon / \sim /$ ' $i$ i /, SPE posits the underlying opposition $/ \varepsilon / \sim / \bar{\varepsilon} /$, which places both these segments on a par with reference to their height phonologically. SPE, then, stands as a radical challenge to PSA but the alleged psychological reality of such abstract derivational rules in Modern English has been widely challenged in generative phonology and elsewhere (for an overview, see Durand, 1990).

\subsection{Objections to binary feature theory}

Beyond their profound conceptual differences, both PSA and SPE paradigms have in common their endorsement of a given set of distinctive features whose scalar values on the phonetic continuum are filtered down, phonologically, to raw binary oppositions. But the binary doctrine itself is not without its dissenters, such as Ladefoged (1971: 94) for whom the very idea of a divide in the phonetic definition and phonological representation of vowel features bears witness to the "linguistic futility" of the binary tenet. By positing an intermediary distinctive feature [ \pm mid] in English, Ladefoged (1971: 93) was able to account 
phonologically for a fourth degree of aperture and thus assign the multi-valued features [4 high], [3 high], [2 high] and [1 high] to high, mid-high, mid-low and low vowels respectively. Following Ladefoged (1971), whose definition allowed for the notion of a phonetic continuum to be directly integrated within the phonological representation of vowels, Singh (1976: 77) went on to map the vowels of English on a numerical scale along which /i: , u:/, /I, $v /, / \varepsilon, o: /, / \varepsilon I, b /$ and /æ, a: / are respectively defined as [5 high], [4 high], [3 high], [2 high], [1 high] ${ }^{4}$.

Furthermore, the notion of tongue height itself has been deeply criticised. Actual tongue height measurements in the production of English vowels have indeed often been found at variance with their conventional plotting on Jones's (1918) quadrilateral ${ }^{5}$ : e.g. high / I/ vs low /I/, high / $\varepsilon /$ vs mid / $\varepsilon /$, high /æ/ vs mid /æ/ vs low /æ/ (Lass, 1984: 120). While there is evidence that the tongue-arch model of vowel production does correspond to the articulatory manoeuvres of some speakers (Lindau, 1978), cineradiographic readings of English vowels by Ladefoged and his associates (in Lieberman \& Blumstein, 1988) clearly demonstrate a number of mismatches between assumed and actual degrees of lowering of the tongue and the inferior maxillary ${ }^{6}$.

In contrast with the variability observed above, Ladefoged (1971) found the cineradiographic readings of tongue height positions in Ngwe front vowels /i, e, $\varepsilon$, æ/ to coincide precisely with Jones’s (1918) plotting of cardinal vowels. As far as their respective back counterparts /a, o, o, u/ are concerned, however, Ladefoged (1971: 68) found no such correlation and concluded that the notion of equidistant articulatory steps for such vowels was a relevant specification only in terms of their pharyngeal point of constriction, which moves away from the glottis in equidistant steps from $/ \alpha /$ to $/ u$ / on a logarithmic scale. While acknowledging tongue height and pharyngeal constriction as relevant features in the phonetic study of vowel production, Ladefoged (1971: 69) questioned their value for phonological theory, given the variability they bring to the definition of vowel features, and recommended (1971: 73) pre-eminence be given to the auditory-acoustic correlates of distinctive features instead. In terms of the formant frequencies displayed in spectrograms, vowel height is the inverse correlate of the first formant, with F1 being highest for low vowels and lowest for high vowels. Similarly, the front vs back dimension of vowels can be thought of as a reflex of the distance between the first two formants, with F1 and F2 being wide in front vowels and narrow in back vowels. Moreover, the distance between F1 and F2 steadily decreases from high front to low front vowels, which tallies with traditional diagrams that map front vowels on an oblique line ${ }^{7}$. In that respect, formant charts provide a more accurate picture of reality than articulatory descriptions of vowels.

Throughout the development of his distinctive feature theory ${ }^{8}$, Jakobson campaigned devotedly for the primacy of acoustic studies in the phonological definition of features, observing not only the precedence of comprehension over production in child language 
acquisition (Jakobson, 1941) but also the long documented history of subjects who, although they had lost the greater part of their tongue, still managed to produce well-differentiated vowels through supralaryngeal configuration adjustments (Jakobson \& Waugh, 1980: 120121). Such observations do pose a challenge to the claim that distinctive features should be articulatory, but placing emphasis on the receptive side of communication on the grounds that articulation is a means to an end is in itself controversial. Perkell's (1969: 55) cineradiographic measurements of tongue contours in English vowels, for instance, mesh closely with the traditional vowel quadrilateral diagram. Furthermore, as pointed out by proponents of the motor theory of speech perception (Liberman, 1957; Liberman, Cooper, Shankweiler \& Studdert-Kennedy, 1967; Liberman, Harris, Hoffman \& Griffith, 1957), the acoustic signal often does not contain any one invariant feature, contrary to the articulatory signal, which involves a single, unitary manoeuvre.

In light of the above and the fact that the same acoustic effect can be achieved by different articulatory manoeuvres (MacNeilage, 1972), the motor theory of speech perception has argued for a more specialised and abstract level of articulation, one in which motor gestures used by listeners to decode speech to key articulators are said to correspond to the speaker's intentions (Liberman \& Mattingly, 1985: 23). Critics of the motor theory of speech perception, however, have dubbed this epistemological repositioning "the retreat up the vocal tract” (in Durand, 1990: 69). Auditory-acoustic theories of speech perception are in turn challenged by the fact that there usually is no single cue corresponding to a phonetic category —Durand (1990: 69) gauges eighteen potential cues to the voicing distinction — but also by the fact that the correspondence between acoustic and auditory data is very indirect, as attested as early as Peterson and Barney’s (1952) perceptual study of English vowels.

From a phonological point of view, it would seem that the best position to adopt is that advocated by Durand (1990: 69): "Distinctive features are neutral between production and perception. They must not be confused with their actual phonetic implementation. They are abstract, classificatory dimensions which provide a link between the articulatory and acoustic dimensions of speech". One crucial question regarding the phonological representation of English vowels, then, is the following: Are they mapped along a three- or more-tiered height axis? If vowel height is a phonologically relevant feature, then its psycholinguistic reality must be empirically verifiable. In keeping with Trubetzkoy (1929, 1931, 1933), for whom the "linguistic unconscious" served as a phonological compass ${ }^{9}$, Section 2 reports on the rationale and methodology of a sound-symbolism experiment designed to test English speakers' implicit phonological knowledge of vowel height differences. 


\section{EXPERIMENTAL FRAMEWORK}

\subsection{Design}

\subsubsection{Rationale}

Diachronic phonetics and comparative linguistics leave little doubt as to speakers' intuitive understanding of feature (dis)similarities, as evidenced by Wallis (1653) and Wilkins (1668) who, despite giving outlandish articulatory descriptions of English sounds, both recognised voiced and unvoiced stops as different from each other as well as from other sounds ${ }^{10}$.

As far back as Plato's Cratylus, it has often been pointed out that vowel sounds come in all shapes, sizes and colours: "round” or "square”, "large” or "small”, "bright” or "dark”, among other qualities (for a crosslinguistic bibliography on phonetic imagery, see Fónagy, 1980). In his pioneering work on phonetic symbolism, Sapir $(1921,1925,1927,1929)$ firmly established the unconsciously cogent correlation between speakers' perception of vowel-size differences and actual motor-acoustic (dis)similarities in the vowel space. In the case of English, symbolic magnitude patterns appear to be governed by three factors working in unison to present the same picture of a vowel sequence as that found on the symbolic scale: "(1) the receding positions of articulation made by the tongue within the mouth, (2) the decreasing frequencies of vocalic resonance as measured acoustically, and (3) the increasing size of the oral cavity used in pronunciation” (Newman, 1933: 61). Such findings provide a proprioceptive explanation for the long-established perceptual "smallness" of /i/ and "largeness” of /u/: “don't flush for bimmelim, only for bummelum”, were instructed users of Fredriksstadt's public toilets during a great drought in Norway (in Jespersen, 1922: 558).

In the wake of Sapir, Fónagy (1980: 89-109) developped the kinaesthetic basis for sound symbolism into the concept of phonetic metaphor, said to be speakers' symbolic projection of their intersensory image of sounds. In the simplest of symbolic cases, the actual size or volume of the stimulus would be mimetically connected to the articulatory gesture itself, such as the degree of aperture or volume of the resonance chambers. The scope and cross-cultural consistency of phonetic metalanguage also points to more complex patterns arising from associative learning mechanisms that correlate size with pitch (Peterfalvi, 1970: 45). By allowing for both articulatory (i.e. larger/smaller vowel $\leftrightarrow$ wider/narrower airstream $\leftrightarrow[+$ low $] /[+$ high $]$ vowel) and auditory-acoustic (i.e. larger/smaller vowel $\leftrightarrow$ heavier/lighter vowel $\leftrightarrow$ [+compact]/[+diffuse] vowel) responses, phonetic metaphors conveniently circumvent the debate surrounding the intrinsic motor-acoustic content of distinctive features.

\subsubsection{Research question}

By means of a size-sound symbolism experiment on a set of vowels from Southern Standard British English (henceforth SSBE), this study engages with distinctive feature theory as reviewed in Section 1, as well as with the concepts of phonetic symbolism and phonetic 
metaphor accounted for in Section 2.1.1. The purpose of this investigation is to integrate speakers' intersensory image of sounds within feature theory in order to a) test their intuitive phonological knowledge of vowel height differences, and b) evaluate whether their understanding of such differences allows for three or more levels of height phonologically ${ }^{11}$.

\subsubsection{Hypotheses}

In light of Taylor and Taylor (1962), whose empirical study shows that speakers are soundsymbolically insensitive to allophonic variations, it follows that perceived vowel-size differences can be construed as the symbolic projection of their implicit distinctive feature knowledge of vowel height. The following can thus be hypothesized: a) non-random vowelsize rankings in such pairs as $[I] \sim[æ]$ but not $[I] \sim[i:]$ would both support three levels of height and invalidate the SPE Vowel Shift Rule (by virtue of which [I] [i: ] would derive from underlying $/ i / \sim / \bar{\varepsilon} /$ ); b) non-random vowel-size rankings in such pairs as $[\mathrm{I}] \sim[æ]$ and [I] [i: ] would support three levels of vowel height within the SPE Vowel Shift paradigm (i.e. $/ i / \sim / \bar{\varepsilon} /$ ), albeit on the condition that vowel-size rankings prove random in such pairs as $[\varepsilon] \sim[i:]$ (said to derive from $/ \varepsilon / \sim / \bar{\varepsilon} /$ ); c) non-random vowel-size rankings in such pairs as $[I] \sim[æ]$ and $[I] \sim[i:]$ and $[\varepsilon] \sim[i:]$ would support more than three levels of vowel height.

\subsection{Method}

\subsubsection{Participants}

One hundred and twenty adult native speakers of SSBE took part in the experiment reported below. Given the experimental rationale set out in Section 2.1.1, no age or gender data were collected as such factors were deemed unlikely to have any significant effect on vowel-size rankings. Test subjects were randomly recruited from passers-by in the town of Hastings, East Sussex, and asked to complete on the spot a vowel-size questionnaire. Participants reported no formal instruction in phonetics and/or phonology in the past and declared themselves to be local speakers. For this reason, the whole group could be described as phonetically naïve and with an SSBE accent.

\subsubsection{Stimuli}

Vowel oppositions were presented in writing in the form of a randomized list of nonword minimal pairs. The purpose was to minimize motor-acoustic variations resulting from known coarticulation phenomena (Rosner \& Pickering, 1994: 266-341) as well as from lexicosemantic interferences likely to arise in subjects' response to stimuli (Mendousse, 2010).

Following Newman (1933: 64), whose data on the symbolic perception of American English vowels strongly suggest that vowel-size differences are magnified by the coexistence 
of [+back] and [+round] features (see Table 3), front and back vowels were segregated to preclude height differences that would be less readily perceptible due to the concomitant presence of the roundness feature (i.e. higher/lower front unrounded vowel vs lower/higher back rounded vowel).

$[ə],[3:],[\Lambda],[a:],[a v]$ as well as centripetal diphthongs and triphthongs were also discarded for the following reasons: a) [ə] cannot occur in stressed syllables (i.e. minimal pairs); b) phonics trials with native speakers of British English showed a lack of robust phoneme to grapheme correspondences between [av], [avə], [oIə] and ou/ow, our/ower, oir; c) $[\varepsilon \ni],[\tau \ni],[v ə],[a \tau \ni]$ and short monophthongs were not pairable in same-length nonwords due to rewrite rules in pre-rhotic context: $\varepsilon \mathrm{I} \rightarrow \varepsilon ə / \_r$; i $: \rightarrow$ Iə/_r; $\mathrm{u}: \rightarrow$ və/_r; aı $\rightarrow$ aıə/_r (in Lilly \& Viel, 1998a: 39, 58, 66-67).

As a result of the above, the following two sets of six vowels were retained: front

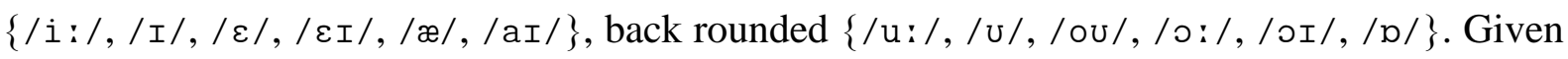
${ }^{\mathrm{n}} \mathrm{C}_{\mathrm{k}}=\mathrm{n} ! /(\mathrm{k} ! \times(\mathrm{n}-\mathrm{k}) !)$, there are fifteen vowel pair combinations within each set. These were presented to subjects in writing in the form of same-length $/(\mathrm{C})(\mathrm{C}) \mathrm{CVC} /$ logatomes.

\subsubsection{Procedure}

Following from Section 2.2.2, participants were handed out a vowel-size questionnaire and asked, in a forced-choice selection task, to circle in each minimal pair the nonword most likely to mean "smaller" or "larger" (fifteen events of each) ${ }^{12}$. The rationale for using the bilateral, forced-choice selection task stems from Jakobson (1963: 241) and Gombrich (1960: 370 ), according to whom intersensory analogies are more readily perceptible through dual patterns. The selection task was presented in the form of an analogy asking subjects to help a comic book company identify in each of its eligible pairs of imaginary names the word whose pronunciation would be best suited to the smaller/larger size of their new line of cartoon figures. Pronunciation and/or instruction clarifications were provided verbally to participants who expressed either difficulty or uncertainty in reading particular nonword tokens and/or completing the questionnaire.

\section{RESULTS}

A total of one hundred and twenty questionnaires were collected, of which six were discarded due to incompletion. Raw figures of symbolic size values for both front and back vowel oppositions are recorded in Tables 1.1 and 1.2 below: 


\begin{tabular}{|c|c|c|c|c|c|c|c|}
\hline & \multicolumn{6}{|c|}{ FRONT VOWELS OPPOSITIONS } & \\
\hline$\rightarrow$ & \multicolumn{6}{|c|}{ “smaller” } & size \\
\hline [i:] & & 60 & 85 & 93 & 82 & 75 & \multirow{6}{*}{$\begin{array}{c}\hat{2} \\
\stackrel{0}{0} \\
\stackrel{0}{0} \\
\stackrel{0}{0}\end{array}$} \\
\hline [I] & 54 & & 78 & 83 & 96 & 87 & \\
\hline$[\varepsilon]$ & 29 & 36 & & 59 & 71 & 90 & \\
\hline$[\varepsilon I]$ & 21 & 31 & 55 & & 75 & 72 & \\
\hline [æ] & 32 & 18 & 43 & 39 & & 63 & \\
\hline [aI] & 39 & 27 & 24 & 42 & 51 & & \\
\hline vowels & [i:] & [I] & {$[\varepsilon]$} & {$[\varepsilon I]$} & {$[æ]$} & [aI] & $\uparrow$ \\
\hline
\end{tabular}

Table 1.1: Raw figures of symbolic size values for SSBE front vowels

\begin{tabular}{|c|c|c|c|c|c|c|c|}
\hline & \multicolumn{6}{|c|}{ BACK VOWEL OPPOSITIONS } & \\
\hline$\rightarrow$ & \multicolumn{6}{|c|}{ "smaller" } & size \\
\hline [u: ] & & 61 & 81 & 79 & 70 & 75 & \multirow{6}{*}{ 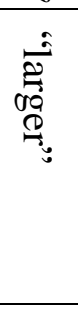 } \\
\hline$[v]$ & 53 & & 84 & 87 & 78 & 94 & \\
\hline [ov ] & 33 & 30 & & 69 & 71 & 46 & \\
\hline$[0:]$ & 35 & 27 & 45 & & 54 & 65 & \\
\hline [OI ] & 44 & 36 & 43 & 60 & & 52 & \\
\hline [o] & 39 & 20 & 68 & 49 & 62 & & \\
\hline vowels & [u: ] & {$[v]$} & [ov ] & [0: ] & [OI] & {$[\mathrm{o}]$} & $\uparrow$ \\
\hline
\end{tabular}

Table 1.2: Raw figures of symbolic size values for SSBE back vowels

A bilateral event is said to be favourable when the highest and lowest of two vowels are respectively identified as "smaller" and "larger", unfavourable elsewhere. Let $\mathrm{H}_{0}$ be the random null hypothesis. If $\mathrm{H}_{0}$ were true each event would follow a Bernoulli trial —either of the values 0 (unfavourable event) and 1 (favourable event) having equal probability (Rees, 1987: 133) — and $\Sigma\{0 ; 1\}$ would follow the binomial distribution $\mathrm{B}(114 ; 0.5)$. Given $n p>5$ and $n(1-p)>5$ (Rees, 1987: 186), $\mathrm{B}(114 ; 0.5)$ can be approximated by normal distribution $\mathrm{N}(0 ; 1)$. Tables 2.1 and 2.2 below indicate for both front and back vowel oppositions results for the $z$-test at the $95 \%$ confidence level:

\begin{tabular}{|c|c|c|c|c|c|c|c|}
\hline & \multicolumn{6}{|c|}{ FRONT VOWELS OPPOSITIONS } & \\
\hline$\rightarrow$ & \multicolumn{6}{|c|}{ "smaller” } & size \\
\hline [i: ] & & $\varnothing$ & + & + & + & + & \multirow{6}{*}{ 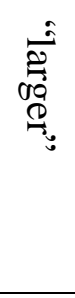 } \\
\hline [I] & $\varnothing$ & & + & + & + & + & \\
\hline$[\varepsilon]$ & - & - & & $\varnothing$ & + & + & \\
\hline$[\varepsilon I]$ & - & - & $\varnothing$ & & + & + & \\
\hline [æ] & - & - & - & - & & $\varnothing$ & \\
\hline [aI] & - & - & - & - & $\varnothing$ & & \\
\hline vowels & [i:] & {$[\mathrm{I}]$} & {$[\varepsilon]$} & {$[\varepsilon I]$} & [æ] & {$[\mathrm{aI}]$} & $\uparrow$ \\
\hline
\end{tabular}

Table 2.1: Z-test outcome to the binomial distribution of symbolic size values for SSBE front vowels (where $\varnothing=\mathrm{H}_{0}$ true and $\pm=\mathrm{H}_{0}$ untrue) 


\begin{tabular}{|c|c|c|c|c|c|c|c|}
\hline & \multicolumn{6}{|c|}{ BACK VOWEL OPPOSITIONS } & \\
\hline$\rightarrow$ & \multicolumn{6}{|c|}{ "smaller" } & size \\
\hline [u: ] & & $\varnothing$ & + & + & + & + & \multirow{6}{*}{ 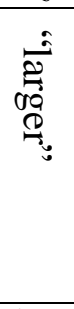 } \\
\hline$[v]$ & $\varnothing$ & & + & + & + & + & \\
\hline [ov ] & - & - & & + & + & - & \\
\hline$[0:]$ & - & - & - & & $\varnothing$ & $\varnothing$ & \\
\hline [OI ] & - & - & - & $\varnothing$ & & $\varnothing$ & \\
\hline [0] & - & - & + & $\varnothing$ & $\varnothing$ & & \\
\hline vowels & [u: ] & {$[v]$} & [ov ] & [0: ] & [OI] & [o] & $\uparrow$ \\
\hline
\end{tabular}

Table 2.2: Z-test outcome to the binomial distribution of symbolic size values for SSBE back vowels (where $\varnothing=\mathrm{H}_{0}$ true and $\pm=\mathrm{H}_{0}$ untrue)

\section{DISCUSSION}

Tables 2.1 and 2.2 above provide significant clues regarding subjects' implicit phonological knowledge of vowel height differences. The non-rejection of the null hypothesis in $\{[I] \sim[i:],[\varepsilon] \sim[\varepsilon I],[æ] \sim[a I]\}$ and $\{[U] \sim[u:],[o:] \sim[O I],[0:] \sim[D],[D] \sim[o I]\}$ strongly suggests that front and back vowels are mentally plotted along a three-tiered height axis. These findings are in keeping with both PSA and SPE analyses (see Section 1.1), which respectively define high, mid and low vowels as acoustic [+diffuse/-compact], [-diffuse/-compact], [-diffuse/+compact] and articulatory [+high/-low], [-high/-low], [-high/+low]. Results coincide, on the whole, with Jones's (1918) height plottings in RP English on the vowel quadrilateral when the latter is placed within the framework of binary feature theory (i.e. front vowel rankings $\{/ i:, I /</ \varepsilon, \varepsilon I /</ æ$, aI $\}$, back vowel rankings $\{/ \mathrm{u}:, \mathrm{v} /</ \mathrm{ov} /</$ oI, $\mathrm{o}: /\})$. From a psycholinguistic point of view, such vowel-size rankings call into question the need, in the name of so-called phonetic realism, for all vowels to be phonologically distinct from one another in terms of motor-acoustic height.

With regard to back vowels, however, results are at odds with the revised equal midvowel height plottings of / : / and / I / recorded in Lilly and Viel (1998b: xi). Although [ov] was "correctly" perceived as symbolically smaller than both [o: ] and [oI], it was “incorrectly" perceived as symbolically larger than [o]. Bearing in mind that $[\mathrm{o}] \sim[\mathrm{ov}]$ originates from single-letter vs double-letter appearance of stimuli (i.e. $o \sim o a$ ) while both [०: ] [ov] and [OI] [ov] originate from double-letter vs double-letter (i.e. or oa and $o y \sim o a$ ), this irregularity could result from orthographic interference caused by participants' response to written stimuli. This is a tentative hypothesis, however, as in the case of $[\varepsilon] \sim[i:] — o r i g i n a t i n g$ from $e \sim e e-[i:]$ was "correctly" perceived as being symbolically smaller than $[\varepsilon]$.

Furthermore, the non-rejection of the null hypothesis in $\{[I] \sim[i:],[v] \sim[u:]\}$ and its simultaneous rejection in $\{[\mathrm{I}] \sim[\mathrm{aI}],[\varepsilon] \sim[\mathrm{i}:],[æ] \sim[\varepsilon I],[\circ] \sim[o v],[\mho] \sim[0:]\}$ go 
against the SPE Vowel Shift Rule by virtue of which one would predict the opposite to be true: deriving surface $[I] \sim[i:]$ and $[v] \sim[u:]$ from underlying $/ i / \sim / \bar{\varepsilon} /$ and $/ u / \sim / \bar{o} /$ incorrectly predicts the null hypothesis to be untrue, while deriving surface $[I] \sim[a I]$, $[\varepsilon] \sim[i:], \quad[æ] \sim[\varepsilon I], \quad[\circ] \sim[o v]$ and $[v] \sim[\circ:]$ from underlying $/ i / \sim / \bar{i} /, / \varepsilon / \sim / \bar{\varepsilon} /$, $/ æ / \sim / \bar{x} /, / \supset / \sim / \bar{\partial} /$ and $/ \mathrm{u} / \sim / \overline{\mathrm{u}} /$ incorrectly predicts the null hypothesis to be true. In line with other psycholinguistic data available in Derwing (1973), Linell (1979) and, more recently, Wang and Derwing (1986) and Jaeger (1986), these findings constitute further empirical evidence against the alleged synchronic psychological reality of the SPE Vowel Shift Rule in the phonology of English.

Setting aside the inconsistency reported in the case of [ov], on the whole results are in keeping with the vowel-size values observed by Newman (1933: 64) in American English. His experimental proportions, based on the symbolic perception of nonword nonword pairs by one hundred and forty-one native speakers of American English, are converted below into percentages:

\begin{tabular}{|c|c|c|c|c|c|c|c|c|c|c|}
\hline & \multicolumn{9}{|c|}{ VOWEL OPPOSITIONS } & \\
\hline$\rightarrow$ & \multicolumn{9}{|c|}{ "small” vs “large” } & size \\
\hline [i: ] & & 54,4 & 77,9 & 73,7 & 63,8 & & & 75,5 & 79,6 & \multirow{9}{*}{ 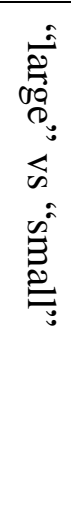 } \\
\hline$[\mathrm{I}]$ & 45,6 & & 73,2 & 87,2 & 77,5 & 72,1 & 83,2 & & 92 & \\
\hline$[\varepsilon I]$ & 22,1 & 26,8 & & 62,3 & & & 49,3 & 57,2 & 75,9 & \\
\hline [æ] & 26,3 & 12,8 & 37,7 & & 59,4 & 62,9 & 60,7 & & & \\
\hline [aI ] & 36,2 & 22,5 & & 40,6 & & 50 & 63,5 & 66,7 & & \\
\hline [ju: ] & & 27,9 & & 37,1 & 50 & & 52,1 & 62,4 & 61 & \\
\hline [u: ] & & 16,8 & 50,7 & 39,3 & 36,5 & 47,9 & & 58 & 53,2 & \\
\hline$[0:]$ & 24,5 & & 42,8 & & 33,3 & 37,6 & 41,1 & & 34,5 & \\
\hline$[a:]$ & 20,4 & 0,80 & 24,1 & & & 39 & 46,8 & 65,5 & & \\
\hline vowels & [i: ] & {$[I]$} & {$[\varepsilon I]$} & {$[æ]$} & [aI ] & [ju: ] & [u: ] & [0: ] & {$[a:]$} & $\uparrow$ \\
\hline
\end{tabular}

Table 3: Percentages of Newman's (1933: 64) experimental proportions on the symbolic size values of American English vowels

By way of an epilogue to Table 3, proportions recorded in Tables 1.1 and 1.2 are converted below into percentages in order to facilitate the comparison of differences and commonalities in the symbolic size rankings of American English and SSBE vowels: 


\begin{tabular}{|c|c|c|c|c|c|c|c|}
\hline & \multicolumn{6}{|c|}{ FRONT VOWELS OPPOSITIONS } & \\
\hline$\rightarrow$ & \multicolumn{6}{|c|}{ "smaller” } & size \\
\hline [i: ] & & 52,63 & 74,56 & 81,58 & 71,93 & 65,79 & \multirow{6}{*}{ 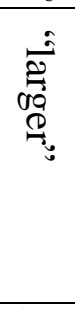 } \\
\hline$[I]$ & 47,37 & & 68,42 & 72,81 & 84,21 & 76,32 & \\
\hline$[\varepsilon]$ & 25,44 & 31,58 & & 51,75 & 62,28 & 78,95 & \\
\hline$[\varepsilon I]$ & 18,42 & 27,19 & 48,25 & & 65,79 & 63,16 & \\
\hline [æ] & 28,07 & 15,75 & 37,72 & 34,21 & & 55,26 & \\
\hline [aI ] & 34,21 & 23,68 & 21,05 & 36,84 & 45,26 & & \\
\hline vowels & [i:] & {$[\mathrm{I}]$} & {$[\varepsilon]$} & {$[\varepsilon I]$} & {$[æ]$} & {$[\mathrm{aI}]$} & $\uparrow$ \\
\hline
\end{tabular}

Table 4.1: Percentages of experimental proportions

on the symbolic size values of SSBE front vowels

\begin{tabular}{|c|c|c|c|c|c|c|c|}
\hline & \multicolumn{6}{|c|}{ BACK VOWEL OPPOSITIONS } & \\
\hline$\rightarrow$ & \multicolumn{6}{|c|}{ “smaller" } & size \\
\hline [u:] & & 53,51 & 71,05 & 69,3 & 61,4 & 65,79 & \multirow{6}{*}{ 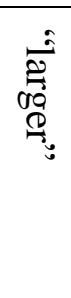 } \\
\hline$[v]$ & 46,49 & & 73,68 & 76,32 & 68,42 & 28,46 & \\
\hline [ov ] & 28,95 & 26,32 & & 60,53 & 62,28 & 40,35 & \\
\hline$[0:]$ & 30,7 & 23,68 & 39,47 & & 47,37 & 57,02 & \\
\hline [OI ] & 38,6 & 31,58 & 37,72 & 52,63 & & 45,61 & \\
\hline$[\mathrm{p}]$ & 34,21 & 17,54 & 59,65 & 42,98 & 54,39 & & \\
\hline vowels & [u: ] & {$[v]$} & [ov ] & {$[0:]$} & [OI ] & {$[\mathrm{o}]$} & $\uparrow$ \\
\hline
\end{tabular}

Table 4.2: Percentages of experimental proportions on the symbolic size values of SSBE back vowels

The above findings have considerable implications for phonological theory as they invalidate the counterclaims traditionally put forward against the three-tiered height representation of English vowels. Subsequently, they also invalidate motor-acoustic height as a phonologically relevant feature in both $[I] \sim[i:]$ and $[v] \sim[u:]$ vowel oppositions. Advanced Tongue Root/Retracted Tongue Root (henceforth ATR/RTR), a feature first described by Pike (1947: 21-22) and appended to the SPE-feature inventory by Halle and Stevens (1969) as an alternative to vowel tenseness to allow for a fourth level of height, seems an equally unlikely candidate. Were $[ \pm$ ATR/RTR] a relevant phonological feature for SSBE vowels, it is assumed that participants would have responded symbolically to the ATRassociated widening of the pharyngeal cavity in the production of [i: ] and [u: ] by assigning "smaller" and "larger" vowel-size values to $[\mathrm{I}] /[\mathrm{v}]$ and $[i:] /[\mathrm{u}:]$ respectively. Tables 2.1 and 2.2 show, however, that this is not the case, which in turn begs the question of how to differentiate between such vowels phonologically. Vowel nuclei in RP English have alternately been described as short monophthongal vs long monophthongal vs diphthongal (i.e. $/ \mathrm{V} / \sim / \mathrm{V}: / \sim / \mathrm{VV} /$ ) following Jones (1918), and simplex vs complex (i.e. $/{ }^{\prime} \mathrm{V} / \sim /{ }^{\prime} \mathrm{V}_{1} \mathrm{~V}_{1} / \sim /{ }^{\prime} \mathrm{V}_{1} \mathrm{~V}_{2} /$ ) following Jakobson, Fant and Halle (1952). Short long and/or simplex $\sim$ complex feature oppositions are therefore obvious candidates. 


\section{CONCLUSION}

We showed in Section 1 that, since the advent of distinctive feature theory, vigorous debate has focused on the divide between the phonetic definition and phonological representation of vowel height in English: Are vowel height features unary, binary, or $n$-ary? Are such features defined acoustically and/or articulatorily? Are vowels plotted against of a three- or moretiered height axis? In light of these questions, Section 2 went on to report on the rationale and methodology of a sound-symbolism experiment designed to test the symbolic size perception that English speakers have of English vowels in order to assess their implicit knowledge of distinctive height differences. To this end, we tabulated in Section 3 and analysed in Section 4 front and back vowel-size rankings collected from a group of phonologically, naïve native speakers of SSBE.

On the whole, although they do not support the Vowel Shift Rule hypothesis advocated in SPE, data mesh closely with Jones's (1918) front and back height plottings in RP English on the vowel quadrilateral when the latter is placed within the framework of binary feature theory (i.e. $\{/ i:, I /</ \varepsilon, \varepsilon I /</ æ$, aI $/\},\{/ u:, v /</ o v /</ o I, o: /\}$ ). The vowel [ov], however, was "incorrectly" perceived as symbolically larger than [o], an idiosyncrasy that was tentatively argued as resulting from orthographic interference caused by participants' response to written stimuli.

The above findings strongly support three levels of height in the phonological definition of SSBE vowels. Furthermore, they invalidate both motor-acoustic height and [ \pm ATR/RTR] as phonologically relevant features in the case of both $[I] \sim[i:]$ and $[u] \sim[u:]$ vowel oppositions. In light of such results, short long and/or simplex complex feature oppositions were suggested, pending further research, as likely candidates for the phonological discrimination of such vowel oppositions.

\section{NOTES}

1. The present article develops from the author's unpublished doctoral thesis (Mendousse, 2003).

2. The set of twelve monophthongs (i.e. short /I, $\varepsilon$, æ, ə, $v, \Lambda, p /$, long /i : , $\alpha$ : , u : , 3 : , o : /) and eight diphthongs (i.e. centrifugal / $\varepsilon I$, aI, $\supset I$, , $\mho$, a /, centripetal / Iə, $\varepsilon \ni$, $\circlearrowright ə /$ ) of RP English accounted for in Jones (1918) was thus reduced to unstressed / $i, e, a, \ominus, u, o /$ and stressed / ' $i$, 'e, 'a, 'ə, 'u, 'o/.

3. For a detailed critical account of distinctive feature differences and commonalities in structural and transformational generative phonology, see Demaegd (2002) and Viel (1984).

4. Singh (1976: 76) records alternative notations such as [high 1], [high 2], [mid 1], [mid 2] and [low].

5. Jones's (1918) vowel quadrilateral — developed in the wake of Bell (1867), Sweet (1877) and the International Phonetic Association (Passy, 1888) — is defined by a set of cardinal of vowels (i.e. front $[i, e, \varepsilon, a]$ and back $[a, \supset, o, u]$ ) said to form equal degrees of acoustic separation and 
which serve as reference points for the comparison of approximate tongue positions in vowel production.

6. Following a detailed comparison of tongue heights in X-ray tracings of vowel systems, it has been claimed that tongue height is hardly phonologically relevant for vowels (in Durand, 1990: 65).

7. Helmholtz (1863) was the first to show that [e], [i ], [ø] and [y] were defined, contrary to previous belief (Willis 1830), by two distinct formants as opposed to the unique resonance of [a ], [o ] and [u ]. Essner (1947) later discovered the correlation between the first two formants and the vowel quadrilateral diagram as inherited from Jones (1918). The analogy between both the acoustic and articulatory vowel quadrilaterals was subsequently confirmed by Delattre (1948), Joos (1948), and Potter and Peterson (1948).

8. For an exegetic account of Jakobson's earlier phonological models through to his fully developed theory of distinctive features, see Mendousse (2007).

9. For a critical reading of Trubetzkoy's (1939) later dismissal, see Viel (1984).

10.Cases not limited to English include a $12^{\text {th }}$-century anonymous Icelandic grammarian, who made use of diactrics to indicate distinctive vowel length and nasality, and Czech spelling-reformer Jan Hus, who distinguished diacritically between the acute and diffuse counterparts of compact palatal consonants (in Jakobson \& Waugh, 1980: 31). Jones (1957: 188) also cites King Sejong, who subsumed under a single letter all four allophones of Korean bilabial stops.

11.The influence of Viel's (1978, 1979, 1981, 1983, 1986) groundbreaking experiments on the implicit feature and markedness knowledge of French native speakers is acknowledged here.

12.Stimuli consist of thirty pairs of (C)(C)CVC logatomes: a) "smaller": fruke frook, smeef smife, splack splike, skogg skoag, glipp glape, smoyz smooz, slaze slize, blook blork, swake sweck, spoyg spogg, floob florb, flazz flezz, grook grock, smeke smake, stapp stipp; b) "larger": splorb splobb, spabe spabb, skloat skloyt, froop fropp, zabb zeeb, bleff bliff, flook floyk, shoak shuke, fleeb flebb, zoak zork, sklite sklett, smipp smeep, blort bloyt, sloak slook, drick drike.

\section{REFERENCES}

Bell, M. (1867). Visible Speech: the Science of Universal Alphabetics. London: Simpkin, Marshall and Co.

Chomsky, N. \& Halle, M. (1968). The Sound Pattern of English. New York: Harper and Row.

Delattre, P. C. (1948). Un triangle acoustique des voyelles orales du français. French Review, 21, 477484.

Demaegd, A. (2002). La notion de marque en phonologie: 1930-2002. Unpublished Doctoral Dissertation, Paris-Sorbonne University, France.

Derwing, B. L. (1973). Transformational Grammar as a Theory of Language Acquisition: a Study in the Empirical, Conceptual and Methodological Foundations of Contemporary Linguistics. Cambridge: Cambridge University Press.

Durand, J. (1990). Generative and Non-Linear Phonology. London: Longman.

Essner, C. (1947). Recherches sur la structure des voyelles orales. Archives Néerlandaises de Phonétique Expérimentale, 20, 40-77.

Fónagy, I. (1980). La métaphore en phonétique. Studia Phonetica, 16, 1-220. (Original work published 1963).

Gombrich, E. H. (1960). Art and Illusion: a Study in the Psychology of Pictorial Representation. New York: Princeton University Press.

Halle, M. \& Stevens, K. N. (1969). On the feature “advanced tongue root”. MIT Quarterly Progress Report, 94, 209-215.

Hart, J. (1569). An Orthographie, Conteyning the Due Order and Reafon, Howe to Write or Paint Thimage of Mannes Voice, Most Like to the Life or Nature. (Facsimile ed.). English Linguistics, 209, 1-80.

Helmholtz, H. L. F. von (1863). Lehre von den Tonempfindugen als Physiologische Grundlage für die 
Theorie der Musik. Braunschweig: Vieweg and Sohn.

Jaeger, J. J. (1986). On the acquisition of abstract representations for English vowels. Phonology Yearbook, 3, 71-97.

Jakobson, R. (1941). Kindersprache, Aphasie und Allgemeine Lautgesetze. In S. Rudy (Ed.), Roman Jakobson: Selected Writings (Vol. 1, pp. 328-401). The Hague: Mouton.

Jakobson, R. (1949). On the identification of phonemic entities. In S. Rudy (Ed.), Roman Jakobson: Selected Writings (Vol. 1, pp. 418-425). The Hague: Mouton.

Jakobson, R. (1963). Linguistique et poétique. (N. Ruwet., Trans.) In R. Jakobson, Essais de Linguistique Générale (Vol. 1, pp. 209-248). Paris: Editions de Minuit (Original work published 1960).

Jakobson, R., Fant, G. \& Halle, M. (1952). Preliminaries to Speech Analysis: the Distinctive Features and their Correlates. In S. Rudy (Ed.), Roman Jakobson: Selected Writings (Vol. 8, pp. 585654). Berlin: Mouton.

Jakobson, R. \& Waugh, L. R. (1980). La charpente phonique du langage (A. Kihm, Trans.) Paris: Editions de Minuit (Original work published 1979).

Jespersen, O. (1922). Symbolic value of the vowel $i$. In O. Jespersen, Selected Writings of Otto Jespersen (pp. 557-577). London: George Allen and Unwin; Tokyo: Senjo Publishing.

Jones, D. (1918). An Outline of English Phonetics. Cambridge: Heffer and Sons.

Jones, D. (1957). The history and meaning of the term "phoneme”. In W. E. Jones \& J. Laver (Eds.), Phonetics In Linguistics: A Book Of Readings (pp. 187-204). London: Longman.

Joos, M. (1948). Acoustic phonetics. Language Monographs, 23, 1-136.

Ladefoged, P. (1971). Preliminaries to Linguistic Phonetics. Chicago: University of Chicago Press.

Lass, R. (1984). Phonology: an Introduction to Basic Concepts. Cambridge: Cambridge University Press.

Liberman, A. M. (1957). Some results of research on speech perception. Journal of the Acoustical Society of America, 29, 117-123.

Liberman, A. M., Cooper, F. S., Shankweiler, D. P. \& Studdert-Kennedy, M. (1967). Perception of the speech code. Psychological Review, 74, 431-461.

Liberman, A. M., Harris, K. S., Hoffman, H. S. \& Griffith, B. C. (1957). The discrimination of speech sounds within and across phoneme boundaries. Journal of Experimental Psychology, 54, 358368.

Liberman, A. M. \& Mattingly, I. G. (1985). The motor theory of speech perception revised. Cognition, 21, 1-36.

Lieberman, P. \& Blumstein, S. E. (1988). Speech Physiology, Speech Perception, and Acoustic Phonetics. Cambridge: Cambridge University Press.

Lilly, R. \& Viel, M. (1998a). La Prononciation de l'Anglais: Règles Phonologiques et Exercices de Transcription. (Revised and augmented ed.). Paris: Hachette.

Lilly, R. \& Viel, M. (1998b). Initiation Raisonnée à la Phonétique de l'Anglais. (Revised and augmented ed.). Paris: Hachette.

Lindau, M. (1978). Vowel features. Language, 54, 541-563.

Linell, P. (1979). Psychological Reality in Phonology: a Theoretical Study. Cambridge: Cambridge University Press.

MacNeilage, P. F. (1972). Speech physiology. In J. H. Gilbert (Ed.), Speech And Cortical Functioning (pp. 1-72). New York: Academic Press.

Mendousse, K. (2003). Pour une phonologie de la perception: De la théorie des traits distinctifs à l'épreuve de la conscience phonologique en anglais. Unpublished Doctoral Dissertation, ParisSorbonne University, France.

Mendousse, K. (2007). Le dilemme de Roman Jakobson face à l'opposition de tension/laxité vocalique. Histoire Epistémologie Langage, 29(1), 29-68.

Mendousse, K. (2010). De la vertu préventive des logatomes contre le parasitage lexico-sémantique. Etudes Anglaises, 63(4), 451-463.

Newman, S. S. (1933). Further experiments in phonetic symbolism. American Journal of Psychology, 45, 53-75.

Passy, P. (1888). Our revised alphabet. The Phonetic Teacher, 57-60. 
Perkell, J. S. (1969). Physiology of Speech Production: Results and Implications of a Quantitative Cineradiographic Study. Cambridge: MIT Press.

Peterfalvi, J.-M. (1970). Recherches Expérimentales sur le Symbolisme Phonétique. Paris: CNRS.

Peterson, G. E. \& Barney, H. L. (1952). Control methods used in a study of the vowels. In I. Lehiste (Ed.), Readings In Acoustic Phonetics (pp. 118-127). Cambridge: MIT Press.

Pike, K. L. (1947). Phonemics: a Technique for Reducing Languages to Writing. Ann Arbor: University of Michigan Press.

Potter, R. K. \& Peterson, G. E. (1948). The representation of vowels and their movements. Journal of the Acoustical Society of America, 20, 528-535.

Rees, D. G. (1987). Foundations of Statistics. London: Chapman and Hall.

Rosner, B. S. \& Pickering, J. B. (1994). Vowel Perception and Production. Oxford: Oxford University Press.

Sapir, E. (1921). Language: an Introduction to the Study of Speech. New York: Harcourt, Brace and World.

Sapir, E. (1925). Sound patterns in language. In D. G. Mandelbaumm (Ed.), Selected Writings of Edward Sapir in Language, Culture and Personality (pp. 33-60). Berkeley: University of California Press.

Sapir, E. (1927). Language as a form of human behavior. English Journal, 16, 413-433.

Sapir, E. (1929). A study in phonetic symbolism. In D. G. Mandelbaumm (Ed.), Selected Writings of Edward Sapir in Language, Culture and Personality (pp. 61-72). Berkeley: University of California Press.

Singh, S. (1976). Distinctive Features: Theory and Validation. Baltimore: University Park Press.

Sweet, H. (1877). A Handbook of Phonetics. Oxford: Clarendon Press.

Taylor, I. K. \& Taylor, M. M. (1962). Phonetic symbolism in four unrelated languages. Canadian Journal of Psychology, 16, 344-356.

Trager, G. L. \& Smith, H. L. (1951). An outline of English structure. Studies in Linguistics: Occasional Papers, 3, 1-91.

Trubetzkoy, N. S. (1929). Zur allgemeinen Theorie der phonologischen Vocalsysteme. Travaux du Cercle Linguistique de Prague, 1, 39-67.

Trubetzkoy, N.S. (1931). Die phonologischen Systeme. Travaux du Cercle Linguistique de Prague, 4, 96-116.

Trubetzkoy, N. S. (1933). La phonologie actuelle. Journal de Psychologie, 30, 227-246.

Trubetzkoy, N. S. (1939). Grundzüge der Phonologie. Travaux du Cercle Linguistique de Prague, 7 , $1-272$

Viel, M. (1978). Pour une phonologie de la perception. Travaux du Centre Interdisciplinaire et de Recherche sur l'Expression Contemporaine, 22, 23-46.

Viel, M. (1979). The perception of distinctive features. Current Issues in the Phonetic Sciences, 9, 787-799.

Viel, M. (1981). Le rôle de la marque phonologique dans la reconnaissance de la simplicité. Modèles Linguistiques, 3(2), 84-97.

Viel, M. (1983). Traits articulatoires et traits de perception dans le consonantisme français. Modèles Linguistiques, 5(1), 155-182.

Viel, M. (1984). La Notion de Marque chez Trubetzkoy et Jakobson: un Episode de l'Histoire de la Pensée Structurale. Lille: Lille III University; Paris: Didier-Erudition.

Viel, M. (1986). L'Ile Déserte Phonologique: Essai de Psycho-Phonétique Quantitative. Paris: DidierErudition.

Wallis, J. (1653). Grammatica Linguae Anglicanae. Cui Praefigitur de Lolequa, sive Sonorum Formatione Tractatus Grammatico-Physicus. Hamburg: G. Schultzen.

Wang, S.-Y. \& Derwing, B. (1986). More on English vowel shift: The back vowel question. Phonology Yearbook, 3, 99-116.

Wilkins, J. (1668). An Essay towards a Real Character and a Philosophical Language. (Facsimile ed.). English Linguistics, 119, 1-454.

Willis, R. (1830). On the vowel sounds, and on reed organ-pipes. Transactions of the Cambridge Philosophical Society, 3, 231-268. 